\title{
The Effects of the Audit Committee Independence and Expertise on Firms' Value, an Empirical Study on Palestine Empirical Study on Palestine
}

\section{Mohammed Azam (Corresponding Author)}

School of Accounting, Dongbei University of Finance and Economics, Dalian, Liaoning, China Email: mazzam1988@gmail.com

\section{Man Wang}

School of Accounting, Dongbei University of Finance and Economics, Dalian, Liaoning, China Email: manwang@dufe.edu.cn

\author{
Article History \\ Received: January 10, 2021 \\ Revised: February 15, 2021 \\ Accepted: February 23, 2021 \\ Published: February 27, 202 \\ Copyright (C) 2021 ARPG \& \\ Author \\ This work is licensed under the \\ Creative Commons Attribution \\ International \\ () (1) CC BY: Creative \\ Commons Attribution License \\ 4.0
}

\begin{abstract}
This study examined the influence of the characteristics of the audit committee on Palestinian firms' value. The research explores precisely the effect on the Audit Committee characteristics' efficiency, namely, independence, expertise, evaluating the relationship among dependent and independent variables. Secondary data collected from a list of companies were registered in the Palestine Stock Exchange from 2011 to 2018. Individual variables considered are the independence \& expertise of the audit committee, whereas the ROA is employed as the dependent variable as an indicator of a firm's value. The results showed that the Audit Committee's independence \& expertise substantially positive with ROA. The study concluded that the audit committee's characteristics are enhancing firm performance. The implications of this study's findings can be used by decisions and policymakers, the firm's management, and other stockholders' interests to create reliable ties between agents and the principals.
\end{abstract}

Keywords: Audit committee independence; Expertise; PSE; Firm value; Palestine.

\section{Introduction}

In the meantime, sub-board committees are set up and appointed with a role for the same attempt to enhance board governance. The Audit Committee is an instance of this. As set out in the Code of Corporate Governance, the audit committee is responsible for evaluating firm financial procedures and the company's financial position (Saat et al., 2012). The Audit Committee also monitors internal control procedures to ensure that codes are properly respected (Gendron et al., 2004). About external audits, the committee must nominate and mediate an external auditor and management to ensure that external auditors are terminated (Gibbins et al., 2010).

The audit committee must be impartial to carry out an efficient supervision and pay greater attention to information (Abbott et al., 2000). Research shows that the external committee director's involvement strengthens the committee's objectivity (Be' dard et al., 2004). Audit committee proactivity would further enhance corporate governance, safeguard shareholders, and reduce the imbalance of asset pillage and information (Turley and Zaman, 2004). As a result, company efficiency is increased by enhancing the Board's oversight and decreased information asymmetry through the participation of an efficient committee. This also alleviates the dilemma of the Department as the audit committee requests that the details be duly disclosed (Gibbins et al., 2010). The following research question is directly addressed by this study:

Different financial irregularities place greater liability on the board. Those financial irregularities raised concerns about the audit committee's monitoring efficacy in conflict resolution (Ebrahim, 2007). The principle suggests that the audit committee should uphold the credibility of financial statements. Access to financial irregular reports is also the responsibility of the audit committee (Klein, 2002). The audit committee plays a crucial role in strengthening coordination gaps and reducing the inconsistencies between the management and the external auditor. The action of the monitoring management therefore expects to constrain future exploitation and supplies the necessary information to the external auditor.

The connection between the financial report and the audit committee currently has contradictory analytical findings. Companies that create and audit committee should generate accurate financial reports in compliance with the postulation agency and some empirical findings. The independence of the Audit Committee has been found by Carcello and Neal (2000) to decrease the likelihood that auditors report. The Rezaee et al. (2003) results, however, indicate that otherwise. In the creation of the Audit Committee, his results do not boost financial information reliability.

In a country like Palestine, the need for research on the relation between audit committee and business performance is significant. This is due to efforts by the country in seeking structures of corporate governance that boost corporate performance and thus draw more foreign investment. There are very few papers still available on the 
study, considering the various reports on the audit committee and firm achievements in Iraq. The following subheadings address the factors defining the efficacy of the audit committee in previous studies.

\section{Literature Review and Hypothesis Development}

Audit committees are responsible for oversight. The supervisory role of the audit committee is made more successful when the Committee, management and the Board of Directors have a working relationship (IIA Institute of Internal Auditors, 2009). Apparently, the audit committee's supervisory role as a sub-committee of the board deals with financial statements. As they control the board and give them added assurance, their presence is also very important. An audit committee's key role is to assist in resolving conflicts of interests between the board and the management. If you comply perfectly with the Corporate governance code, the result would be favourable. A welldefined position, skilled staff and professionalism are important factors that improve the audit committee's efficiency. Moreover, coordination between the audit committee, the board, the external and internal auditors would enhance the effectiveness of the audit committee.

Prior literature analysed the relationship between audit committee and firms value. Puni (2015) A sample of the Ghana Stock Exchange from 2006 to 2010 examined and identified the positive correlation between ROA, ROE and the audit committee life. The analysis of the different role of auditing boards on management was analyzed by Ghafran and O'Sullivan (2013). The results of the audit committee on the stock market response indicate that investors trust the setting up of audit committees. Beasley et al. (2009) It claimed that in relation to the establishment of the audit committee is the high reporting framework. In addition, from 2010 to 2011, the analysis of 80 companies listed on the Karachi Stock Exchange was conducted by Muhammad et al. (2016). The study established a positive relationship with firm performance using ROA and ROO as metrics between the presence of the audit committee.

In Bangladesh, Rouf (2012) the relationship between firm value in the Dhaka Stock Exchange has been studied (measured via ROE and ROA), the presence of an audit committee using 93 listed non-financial firms, and a significant relationship has been established.In other words, between 2006 and 2007 Bremert and Schulten (2008) investigated 160 listed German companies and found a negative relationship between firm results and the existence of the Audit Committee by using ROA and Tobin's Q as indicators.

The content of the financial statements of any company can only be accepted on the basis of certain claims put forth by the previous investigations if the audit committee exists. This is supported by the Agency's hypothesis by referring the committee as another internal management tool. Table 1 thus summarizes the findings of the empirical studies discussed above about the relationship between company success and the existence of the audit committee.

\subsection{Audit Committee Independence}

In separate corporate ownership and the problem of agency conflicts in monitoring performance, an efficient audit committee is needed as part of the corporate process. The Board consists of an audit committee that functions actively for the sake of corporate governance. The independence of the audit committee is a crucial problem in previous studies. Under these literatures, the audit committee enhances reporting independently of the audit committee (Lin et al., 2006). As stated under the Corporate Governance Code, the Audit Committee makes an important contribution to ensuring that corporate values are essential because of the independence and professional actions of the committee members. A combined sample from Singapore and Malaysia was used by Bradbury et al. (2006) to analyze the correlation between accounting quality and the composition of the audit committee. The results of the study indicate that the independence of the audit committee increases earnings efficiency.

The relation between independence of the audit board and firm performance was recently investigated by Hamdan et al. (2013) on the list of stock exchange companies in Amman. The audit committee's independence enhances the company's efficiency. The audit committee's position affect the performance of the ROA and ROE performance proxies on a sample of Tunisia-listed firms from 2007 to 2010, according to Bouaziz and Triki (2012).The audit committee's independence has been shown in relation to the success of businesses. The independence of the audit committee and the financial results of Oman are significantly positive (Al-Matari et al., 2014).

Conversely, no connection exists between the independence of the audit committee and the financial results of Indian companies (Bansal and Sharma, 2016).On the contrary, as reported by Robin and Amran (2016), there are negative links between independent audit committee and firm performance (2016). The analysis was carried out in 122 Indonesia Stock Exchange family-owned listed companies between 2010 and 2014. There is also a negative relationship between Dar et al. (2011) from Pakistan. Wakaba (2014), found in Kenya that the audit committee has a negative correlation with the company's results.

The independence of the manager would thus assist them to reduce their credibility and offer a quality corporate decision. The independence of the Audit Committee from the point of view of Palestine would allow the members to determine their financial reporting policy, the external audit process, the auditor's independence and the financial condition of the company in an objective and impartial manner we thus hypothesis the following hypothesis:

H1: Audit committee independence positively affect firm's value.

\subsection{Audit Committee Expertise}

Themes that bother about the efficacy of the audit committee have increased in recent years, based on committee members' expertise and knowledge. The Board of Directors' duty shall ensure that the financial statement 
is accurate and valid in order to ensure that stakeholders can properly evaluate the financial situation (Hamid et al., 2015). Delegates from the board of directors are responsible for supervising the management's financial statements to the audit committee. According to Bradbury (1990), by introducing a sound management structure, both internally and externally, the integrity of the financial reporting process is improved by the audit committee. Most citizens have a proper understanding of and knowledge of financial statements to preserve the integrity of the financial reporting standards and to track the financial reporting system effectively.

Recently, regulatory initiatives have made arrangements requiring the member to hold at least one financial competence to enhance the efficiency of the audit committee. Awareness of the audit committee should cover all other areas of the company's operation in excess of accounting and auditing knowledge. The right question can be asked and the management scrutinized with such a knowledge and understanding of the activities of the organization. In several ways, previous research explored the financial expertise of the audit committee as one of the core features of an efficient committee.

The relationship between management supervision, audit committee financial experience and financial report method was investigated in comprehensive studies. There are many empirical findings which support the fact that a financially stable audit committee enhances the quality of the figures (Abbott et al., 2002). DeFond et al. (2005) Empirical results show the positive impacts of investor response on the appointment to audit committee of representatives with financial experience relevant to accounting skills. Regarding financial reporting, a study showed that financial expert audit committee reduced the vigorous reporting process (Be' dard et al., 2004; Dhaliwal et al., 2006). Zhang et al. (2007) companies with internally poor control have stated the members have less financial and non-financial experience. The relation between the audit committee's financial competence and their independence was investigated by Mustafa and Ben Youssef (2010). They stated that the misappropriation of the assets reduced by independent directors with financial expertise. Abernathy et al. (2014) further research showed that accounting knowledge is connected to reducing the latency of financial reporting. It also indicates that the audit committee's accounting expertise enhances the efficacy of the audit committee.

The relationships between the audit committee and expert and firm achievement were reported in Malaysia by Rashidah and Fairuzana (2006) to be positive. In addition, Zábojníková (2016) analyzed the relationship of experience and skills in the audit committee and firm success by ROE steps process. In the London Stock Exchange list 72 British companies were chosen. The study shows that the awareness and experience of the audit committee is optimistic about firm results (ROE). Similarly, there has been a positive correlation among the expertise and expert and firm success of Ojeka et al. (2014), Wakaba (2014), and Amer (2016).

However, the relationship between the expertise of the audit committee and the expert and the company performances was considered negative by Glover-Akpey and Azembila (2016). In 2015, 36 of the listed companies in Ghana were considered by Glover-Akpey and Azembila (2016). For the audit committee expertise, experts and firm results the study found a negative financial expert partnership.

In their studies, Hamdan et al. (2013) both reported positive ROE and EPS and not important ROA and Tobin's Q. Gunes and Atilgan (2016) studied ten Turkish banks and ten UK banks from 2006 to 2010. The research showed that the correlation between expertise and firm performance in the audit committee is negative in Turkish banks but not substantial in the case of ROE-compliance with UK banks.

Consequently, the experience and skills of the audit committee are important in order to ensure active involvement in the evaluation of the appropriateness of management accounting. This research considers this variable to be significant, given the unfinished association between the expertise and the audit committee and the firm value of previous studies we consider the following hypothesis.

\section{H2: Audit committee independence positively affect firm's value.}

\section{Research Design}

\subsection{Sample Selection and Data Collection}

The data gathered from two sources that are companies' annual financial statements listed in Palestine Stock Exchange Market (http://www.pex.ps) and OSIRIS database of financial information. Firms' annual reports are used to collect manually the the number of independent and expertise members of audit committee.

All companies listed on the Palestinian Stock Exchange market are non-financial companies. However, the financial firms listed (banks and insurance companies) are omitted, as they comply with some lows and regulations. Consequently the research population is 34 non-financial listed undertakings, as shown in Table 1, covering the manufacturing, investing and service sectors from 2011 to 2018 We exclude missing value-added company-years, as well as negative and null before-tax revenue observations that result in final results 278 company-year observations.

Table-1. Industry classification

\begin{tabular}{l|l|l}
\hline Sector & No. firms & Percent \\
\hline Service & 12 & 35.3 \\
\hline Industry & 13 & 38.2 \\
\hline Investment & 9 & 26.4 \\
\hline Total & 34 & 100 \\
\hline
\end{tabular}




\subsection{Variable Measurements}

\subsubsection{The Dependent Variable (Firm value)}

ROA is used as measures for profitability in a corporation. Latif et al. (2013), have reported that ROA would be used to calculate the net income divided into total assets by year-end. ROA gives an example of how efficient management in assets is used to provide revenue. The calculation of ROA is by calculated by dividing the annual earning of the firm by its total asset. In this case percentage is used to measure ROA.

$\mathbf{R O A}_{\text {it }}=$ Net income $_{\text {it }} /$ Total Assets

\subsection{The Independent Variables}

\subsubsection{Audit Committee Independence}

The number of Qualified Non-Executive Directors on the audit committee considered to be independent member as stated in Nawafly and Alarussi (2016); Hamdan et al. (2013); Bouaziz and Triki (2012); Robin and Amran (2016).

\subsection{Audit Committee Expertise}

Audit committee expertise of the Audit Committee measures the amount of financial experience of the audit committee (Hamdan et al., 2013; Nawafly and Alarussi, 2016; Ojeka et al., 2014; Wakaba, 2014).

\section{Econometric Specification}

To test our hypotheses, we specify the following ordinary least squares (OLS) regression model:

$R O A_{i t}=\alpha_{0}+\alpha_{1} A_{C I N D E}{ }_{i t}+\alpha_{2}$ ACEXP $_{i t}+\alpha_{5}$ INDTYP $_{i t}+\alpha_{3}$ LEVG $_{i t}++$ YEAR4 it $+e$

Where ACINDE audit committee independence and ACEXP audit committee experience, We also used control variables that could affect companies proprieties, regarding to audit committee independence \& expertise, LEVERG is the percentage of total long-term debts over total assets. Badertscher et al. (2013) resulted a positive relationship between leverage and effects of audit committee cherecterestics. INDTYP it dummy variable; representing three industry types "manufacturing, investment, and service sectors.

\section{Results and Analysis}

\subsection{Descriptive Statistics}

The summary statistics of our dependent and independent variables are listed in Table (2). The mean ROA is .0155 , while the mean values are .132 and .1629 percent for ACIND and ACEXP, respectively. Compared to those stated by Bouaziz and Triki (2012) and Tornyeva and Wereko (2012), these findings indicate a fair effects of audic committee characteristics. The level of independence and experience of the audit committee differs significantly among our firms sampled. ACEXP, the lowest stage of ACIND, is .010 and .019 respectively.

Table-2. Descriptive statistics

\begin{tabular}{|c|c|c|c|c|}
\hline Variables & Mean & SD & Minimum & Maximum \\
\hline ROA & .015 & .0192 & -.52 & .2015 \\
\hline ACINDE & .129 & .2345 & .011 & .152 \\
\hline ACEXP & .159 & .1796 & .018 & .1625 \\
\hline LEVERG & .1239 & .1996 & 0 & .823 \\
\hline INDTYP & .273 & 0.2539 & 0 & 1 \\
\hline
\end{tabular}

\subsection{Correlation Matrix}

The Pearson correlation between variables used in empirical regressions is presented in Table 3. We find ROA and ACINDE and ACEXP correlating significantly, and we have tested multicollinearity among independent variables with the regression model, the correlation between independent variables and VIFs to test the multicoolinarity of Table 4, VIF range from 1.05 to 1.79 below 10 (Neter, 1996).

Table-3. Spearman correlation matrix

\begin{tabular}{l|l|l|l|l|l}
\hline & ROA & ETR1 & ETR1 & LEVERG & INDUS \\
\hline ROA & 1 & & & & \\
\hline ACINDE & $0.676^{* * *}$ & 1 & & & \\
\hline ACEXP & $0.0757^{*}$ & $0.176^{* * *}$ & 1 & & \\
\hline LEVERG & $-0.0130^{*}$ & $-0.0135^{*}$ & $-0.162^{* * *}$ & 1 & \\
\hline INDUS & -0.0672 & $0.0631^{*}$ & -0.0608 & $-0.132 * *$ & 1 \\
\hline
\end{tabular}

Note: ROA is of income before tax scaled by total assets ACINDEP and ACEXP are audit committee independence and experienced members, , LEVER is the ratio of total long-term debts over total assets, INDTYP it dummy variable; representing three industry types "manufacturing, investment, and service sectors.

;**,**,*are significance levels at 1,5 and $10 \%$, respectively 


\subsection{Multivariate Analysis}

Table 4 illustrates the results of the audit committee independence ACINDE, ACEXP on ROA, we can observe positive and statistically significant relationship firm value and audit committee independence and expertis. Table 4 suggest that this results support hypothesis of positive relationship between audit committee independence, expertise and firm value. Tornyeva and Wereko (2012) and Bouaziz and Triki (2012), Al-Matari et al. (2014) Table 4, with the control variables shows that companies with increased business types appear to promote less audit committees' dependency, shows the positive relationships between corporate value and the audit Committee independence and experience. LEVERG has reported positive ties between the independence of the leverage and audit committee and expertise, in accordance with Badertscher et al. (2013).

Table-4. Shows the results of multiple regression analysis using ROA dependent variable

\begin{tabular}{l|l|l|l|l|l}
\hline Variables & Predicted sign & Coef & T-value & Sig & VIF \\
\hline Intercept & & -7.4 & -.73 & .465 & \\
\hline Independent variables & & & & & \\
\hline ACINDE & - & $0.31166^{* *}$ & -1.93 & 0.055 & 1.79 \\
\hline ACEXP & + & $.3618^{*}$ & -1.87 & 0.063 & 1.54 \\
\hline LEVERG & - & $0.0129^{* *}$ & 0.42 & 0.0672 & 1.09 \\
\hline INDUS & - & .5435 & -0.27 & 0.787 & 1.05 \\
\hline Observations & 278 & & & & \\
\hline Adjusted R-squared & .39 & & & & \\
\hline F-test. & 21.40 & & & & \\
\hline Prob > F & .000 & & & & \\
\hline Note $:$ Ta
\end{tabular}

Note : Table 4 report regression results using OLS , ACINDEis is calculated by the number of independent members ROA is of income before tax scaled by total assets, LEVERG is the ratio of total long-term debts over total assets, INDTYP it dummy variable; representing three industry types "manufacturing, investment, and service sectors. ;**,**,*are significance levels at 1,5 and $10 \%$, respectively

\section{Conclusion}

This study explores the impact of the competence and independence of the audit Committee on firm value. In terms of the important market value, we are seeing a positive relationship between firm principles and independence $\&$ the experience of the Audit Committee on the basis of a sample of 34 Palestinian listed companies during 2011 to 2018. Our findings are important in the Palestinian context, which considered exceptional because of the poor security of investor rights. In addition, the stock market in Palestine has not adequately grown. This study has spotlight on audit committee efficiency on unique environment in Palestine and thus extend literature that focused on developed countries. Simultaneously, considered as basis in Palestine and other Arab countries for future research in this area.

Although there are still restrictions on the last consequences of this analysis, one sample is restricted. However, the study encourages the researchers to undertake research into corporate governance in Palestinian and Middle East States to better understand the correlation of successful corporate management to other business variables, since the Palestinian exchange market has few listed companies, as small countries with precarious political circumstances.

\section{References}

Abbott, L. J., Park, Y. and Parker, S. (2000). The effects of audit committee activity and independence on corporate fraud. Managerial Finance, 26(11): 55-68.

Abbott, L. J., Parker, S. and Peters, G. F. (2002). Audit committee characteristics and financial misstatement: A study of the efficacy of certain blue ribbon committee recommendations. Available: https://ssrn.com/abstract=319125 or http://dx.doi.org/10.2139/ssrn.319125

Abernathy, J. L., Beyer, B., Masli, A. and Stefaniak, C. (2014). The association between characteristics of audit committee accounting experts, audit committee chairs, and financial reporting timeliness. Advances in Accounting, 30(2): 283-97.

Al-Matari, E. M., Al-Swidi, A. K. and Fadzil, F. H. (2014). The effect of board of directors characteristics, audit committee characteristics and executive committee characteristics on firm performance in Oman: An empirical study. Asian Social Science, 10(11): 149-71.

Amer, M. (2016). Measuring the effect of the board of directors and audit committee characteristics on firm financial performance in Egypt (Doctoral dissertation). Cardiff Metropolitan University.

Badertscher, B., Shroff, N. and White, H. D. (2013). Externalities of public firm presence: Evidence from private firms' investment decisions. Journal of Financial Economics, 109(3): 682-706.

Bansal, N. and Sharma, A. K. (2016). Audit committee, corporate governance and firm performance: Empirical evidence from India. International Journal of Economics and Finance, 8(3): 103.

Be' dard, J., Chtourou, S. M. and Courteau, L. (2004). The effect of audit committee expertise, independence, and activity on aggressive earnings management. Auditing: A Journal of Practice and Theory, 23(2): 13-35.

Beasley, M. S., Carcello, J. V., Hermanson, D. R. and Neal, T. L. (2009). The audit committee oversight process. Contemporary Accounting Research, 26(1): 65-122. 
Bouaziz, Z. and Triki, M. (2012). The impact of the presence of audit committees on the financial performance of Tunisian companies. International Journal of Management and Business Studies, 2(4): 57-64.

Bradbury (1990). The incentives for voluntary audit committee formation. Journal of Accounting and Public Policy, 9(1): 19-36.

Bradbury, Mak, Y. T. and Tan, S. M. (2006). Board characteristics, audit committee characteristics and abnormal accruals. Pacific Accounting Review, 18(2): 47-68.

Bremert, M. and Schulten, A. (2008). The impact of supervisory board characteristics on form performance. Available: https://madoc.bib.uni-mannheim.de/2337/

Carcello, J. V. and Neal, T. L. (2000). Audit committee composition and auditor reporting. The Accounting Review, 75(4): 453-67.

Dar, L. A., Naseem, M. A., Rehman, R. U. and Niazi, G. S. (2011). Corporate governance and firm performance a case study of Pakistan oil and gas companies listed in Karachi stock exchange. Global Journal of Management and Business Research, 11(8): 1-10.

DeFond, M. L., Hann, R. N. and Hu, X. (2005). Does the market value financial expertise on audit committees of boards of directors? Journal of Accounting Research, 43(2): 153-93.

Dhaliwal, D. S., Naiker, V. and Navissi, F. (2006). Audit Committee Financial Expertise, Corporate Governance and Accruals Quality: An Empirical Analysis. Available: https://ssrn.com/abstract=906690 or http://dx.doi.org/10.2139/ssrn.906690

Ebrahim, A. (2007). Earnings management and board activity: An additional evidence. Review of Accounting and Finance, 6(1): 42-58.

Gendron, Y., Bédard, J. and Gosselin, M. (2004). Getting inside the black box: A field study of practices in "effective" audit committees. Auditing. A Journal of Practice and Theory, 23(1): 153-71.

Ghafran, C. and O'Sullivan, N. (2013). The governance role of audit committees: reviewing a decade of evidence. International Journal of Management Reviews, 15(4): 381-407.

Gibbins, M., McCracken, S. and Salterio, S. E. (2010). The auditor's strategy selection for negotiation with management: Flexibility of initial accounting position and nature of the relationship. Accounting, Organizations and Society, 35(6): 579-95.

Glover-Akpey, I. and Azembila, A. B. (2016). The effect of audit committees on the performance of firms listed on the Ghana stock exchange. Journal of Business and Management, 18(11): 55-62.

Gunes, N. and Atilgan, M. S. (2016). Comparison of the effectiveness of audit committees in the UK and Turkish Banks. International Journal of Financial Research, 7(2): 18.

Hamdan, A. M., Sarea, A. M. and Reyad, S. M. R. (2013). The impact of audit committee characteristics on the performance: Evidence from Jordan. International Management Review, 9(1): 32-41.

Hamid, K. C. A., Othman, S. and Rahim, M. A. (2015). Independence and financial knowledge on audit committee with non-compliance of financial disclosure: A study of listed companies issued with public reprimand in Malaysia. Procedia-Social and Behavioral Sciences, 172: 754-61. Available: https://www.sciencedirect.com/science/article/pii/S1877042815004668

IIA Institute of Internal Auditors (2009). Institute of internal auditors professional guidance. IIA.

Klein (2002). Causes and consequences of variation in audit committee composition. Working paper social Science reserash network.

Latif, B. I. L. A. L., Shahid, M. N., Haq, M. Z. U., Waqas, H. M. and Arshad, A. R. B. A. B. (2013). Impact of corporate governance on firm performance: Evidence from sugar mills of Pakistan. European Journal of Business and Management, 5(1): 51-59.

Lin, J. W., Li, J. F. and Yang, J. S. (2006). The effect of audit committee performance on earnings quality. Managerial Auditing Journal, 21(9): 921-33.

Muhammad, H., Rehman, A. U. and Waqas, M. (2016). The effect of corporate governance practices on firm performance: Evidence from Pakistan. The East Asian Journal of Business Management, 6(1): 5-12.

Mustafa, S. T. and Ben Youssef, N. (2010). Audit committee financial expertise and misappropriation of assets. Managerial Auditing Journal, 25(3): 208-25.

Nawafly, A. T. and Alarussi, A. S., 2016. "Impact of board's characteristics, audit committee characteristics over firm performance." In International Conference on Accounting Studies (ICAS). Langkawi, Kedah, Malaysia.

Neter, J. (1996). Applied linear statistical models. McGraw-Hill: Boston.

Ojeka, S., Iyoha, F. O. and Obigbemi, I. F. (2014). Effectiveness of audit committee and firm financial performance in Nigeria: an empirical analysis. Journal of Accounting and Auditing: Research and Practice: Available: https://ibimapublishing.com/articles/JAARP/2014/301176/

Puni, A. (2015). Do board committees affect corporate financial performance? Evidence from listed companies in Ghana. International Journal of Business and Management Review, 3(5): 14-25.

Rashidah, A. R. and Fairuzana, H. M. (2006). Board, audit committee, culture and earnings management: Malaysian evidence. Managerial Auditing Journal, 21(7): 783-804.

Rezaee, Z., Olibe, K. O. and Minmier, G. (2003). Improving corporate governance: the role of audit committee disclosures. Managerial Auditing Journal, 18(6/7): 530-37.

Robin, X. and Amran, N. F., 2016. "Audit committee characteristics on family firms performance in Indonesia." In International Conference of Accounting Studies (ICAS). Malaysia. pp. 190-94. 
Rouf, A. (2012). The relationship between corporate governance and value of the firm in developing countries: Evidence from Bangladesh. Journal of Economics and Business Research, 18(1): 73-85.

Saat, N. A. M., Karbhari, Y., Xiao, J. Z. and Heravi, S. (2012). Factors affecting independent audit committee members' effectiveness-the case of listed firms on bursa Malaysia. World Review of Business Research, 2(3): 132-47.

Tornyeva, K. and Wereko, T. (2012). Corporate governance and firm performance: Evidence from the insurance sector of Ghana. European Journal of Business and Management, 4(13): Available: https://core.ac.uk/download/pdf/234624331.pdf

Turley, S. and Zaman, M. (2004). The corporate governance effects of audit committees. Journal of Management and Governance, 8(3): 305-32.

Wakaba, R. (2014). Effect of audit committee characteristics on financial performance of companies listed at the Nairobi securities exchange (Doctoral dissertation). University of Nairobi.

Zábojníková, G. (2016). The audit committee characteristics and firm performance: Evidence from the UK.

Zhang, Y., Zhou, J. and Zhou, N. (2007). Audit committee quality, auditor independence, and internal control weaknesses. Journal of Accounting and Public Policy, 26(3): 300-27. 